DOI: 10.17707/AgricultForest.64.2.02

\author{
Robinson Luiz PAULO, \\ Danilo Gualberto ZAVARIZE, Iracy MARTINS ${ }^{1}$
}

\title{
APPL YING NENDO DANGO TECHNIQUE FOR GERMINATION AND PRE-ESTABLISHMENT OF NATIVE SPECIES ON DEFORESTED AREAS
}

\begin{abstract}
SUMMARY
Nendo Dango is a planting technique created by the agriculturist and microbiologist Masanobu Fukuoka, around the 1940's decade, to reforest some zones of the Asiatic continent with tendency to desertification, while developing the Fukuoka method with no-tillage, also called wild agriculture. This paper's goal was to evaluate this technique's efficiency on germination and preestablishment of native species seeds in a deforested area in the Brejo Comprido's stream riverbank, in Palmas, state of Tocantins, Brazil. Eight types of native species seeds were selected, arranging them into lake-originated-clay balls around 2 to $3 \mathrm{~cm}$ large, disposed in 0.5 meters interspacing, forming an experiment field of $8 \mathrm{~m}^{2}$, designed with 5 sample lines and 3 repetitions for statistical analysis, totalizing a $24 \mathrm{~m}^{2}$ area. Nine data acquisitions were made to input into calculation the parameters germination percentage (GP), germination velocity rate (GVR) and required germination time (RGT). Results had shown a GP varying from $26.7 \%$ to $100 \%$, where 5 of the 8 species seeds well-thrived the environment conditions applied, as well as a GVR varying from 0.36 to 1.35 individuals per day and an RGT varying from 0.17 to 0.26 seeds per day. In a general picture, the technique proved to be efficient for the proposed experiment and chosen native species, supplying the seeds with a good pre-environment for successful germination and pre-establishment.
\end{abstract}

Keywords: No-tillage, Seeds germination, Clay balls, Cerrado biome, Reforestation, Wild agriculture

\section{INTRODUCTION}

Human activities have become more frequently the reason of degraded environments appearance nowadays, in terms of deforestation, pollution, agriculture and a serie of other many economic-related actions required to sustain modern life. The recovery of these areas, direct or indirectly, demand priority on reestablish the biota's natural conditions, throughout initiatives and projects whose are less expensive and based on sustainability, primarily (Bastos \&

\footnotetext{
${ }^{1}$ Robinson Luiz Paulo, Danilo Gualberto Zavarize (corresponding author: danilozavarize@uft.edu.br) and Iracy Martins. Laboratory of Environmental Impacts Characterization, Department of Environmental Engineering, Federal University of Tocantins, 109 North, NS 15 Avenue, ALCNO 14, w/n, City of Palmas, state of Tocantins, BRAZIL

Notes: The authors declare that they have no conflicts of interest. Authorship Form signed online.
} 
Ferreira, 2010). Speaking of recovery, since the 1940's decade Masanobu Fukuoka, an agriculturist and microbiologist known by his minimally invasive planting methods, has developed a technique called "Nendo Dango", which consists of placing seeds into clay balls and release these into the environment for replant once-loss threes in deforested or with desertification tendency areas (Fukuoka, 1985). The main purpose of this technique is to protect the seeds from predators and inclement weather, without using any pesticides or herbicides, while involving the seed onto a clay ball, which provides a secure and stable environment for it to germinate and pre-establish into the soil (Fukuoka, 1991). This technique has been used all around the world for the most variated motives, as recovering green urban areas or filling green protected areas in underdeveloped countries in South America, Africa and Asia (Torres, 2010).

The area chosen for the experiment procedures was previously base for a sewage treatment plant, in the city of Palmas, which the degradation became from deforestation and soil pollution, altering the local ecosystem and affecting punctually the Brejo Comprido's riverbank, as well as the water. Once the plant was disabled, the area was abandoned and turned into a place for irregular domestic residues disposal. For the technique to work, the area was cleaned up from all the residues disposed and they were sent to the Palmas' landfill. Thus, this paper's main goal was to evaluate "Nendo Dango" efficiency on germination and pre-establishment of native species' seeds on a deforested area in the Brejo Comprido's stream riverbank, at the city of Palmas, state of Tocantins, Brazil.

\section{MATERIAL AND METHODS \\ Species Selection and Management}

Considering factors as species' genetic variability, most occurrence in remaining riparian wood and easy collection, eight native species, which occur in Cerrado biome, were selected. The seeds were cleaned, let exposed 2 days to dry and stored under temperature between $16^{\circ} \mathrm{C}$ and $18^{\circ}$ at the Laboratory of Environmental Impacts Characterization.

Table 1. Chosen species for the experiment

$\begin{array}{cc}\text { SUCIENTIFIC NAME } & \begin{array}{c}\text { SUCESSIONAL } \\ \text { CLASSIFICATION }\end{array}\end{array}$

Tabebuia roseoalba (Ridl.) Sandwith

Sterculia chicha A. St.-Hil. ex Turpin

Tabebuia heptaphylla (Vell.) Toledo

Anadenanthera falcata (Benth.) Speg

Calophyllum brasiliense Cambess

Guazuma ulmifolia Lam.

Hymenaea stigonocarpa Mart. ex Hayne

Bowdichia virgilioides Kunth
Secondary

Pioneer

Secondary

Pioneer

Secondary/Intermediary

Pioneer

Late Secondary and Climax

Secondary 
For the Nendo Dango technique it is not necessary to scarify or break dormancy of the seeds. Table 1 shows the scientific name and successional classification of the chosen species.

\section{Clay Origins and Management}

For the experiment was used clay originated from the drain work of a lake within the Cesamar Park (Figure 1), also localized at the city of Palmas, under license and supervision of the park's authorized staff. To obtain the material was used pottery shovel and three tow bags.

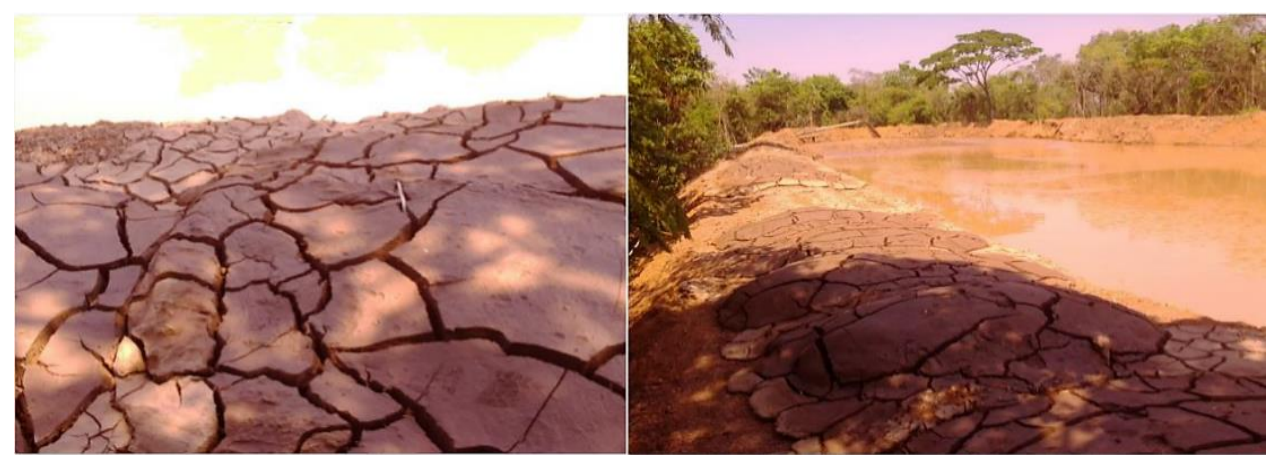

Figure 1: Source of the clay for the experiment

\section{Procedures for Clay Balls Production}

For the method execution, the soil where the clay balls with seeds were released was not plowed, pruned or weeded, as well as applied any type of pesticide, fertilizer or herbicides, as essentially demanded by Fukuoka (1985). The clay removed from the drain work was previously arranged into blocks, which were broken down into smaller pieces with an octave hammer and sifted with a $0.005 \mathrm{~mm}$ sieve. After sifted, four kilos of the clay powder were set aside into a plastic tray, measuring $9.7 \times 30 \times 49 \mathrm{~cm}$. The humidification process was executed by adding half a liter of water onto the powder and hand-mixed until form a consistent and homogeneous mass, enabling it to produce disks to insert the seed and then mold it into firm balls (Figure 2).

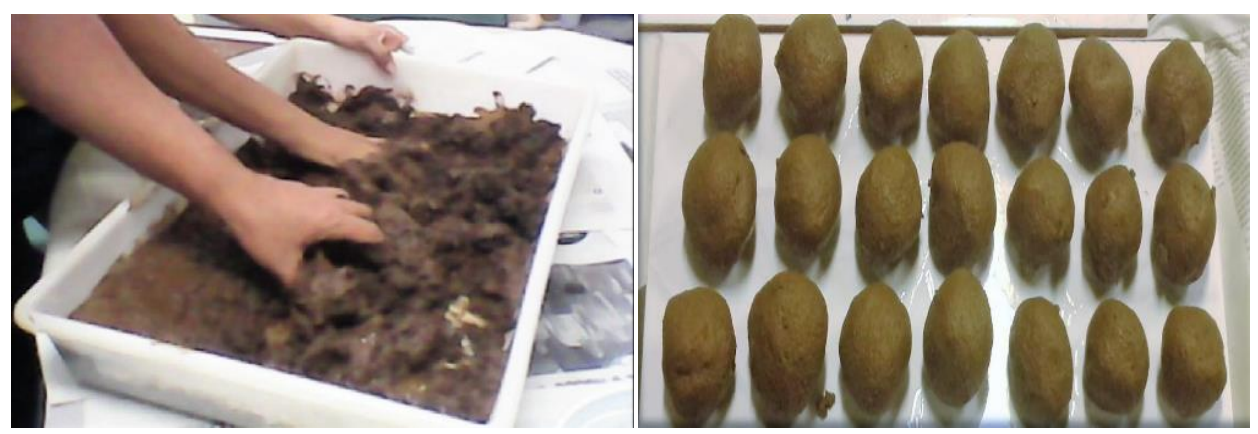

Figure 2: Clay mass and some of the clay balls already seeded 
Each ball weighted an average of $70 \mathrm{~g}$ and had 2 to $3 \mathrm{~cm}$ diameter. This variance of size was dictated by the size of the seed, in order to supply enough clay mass for it to not crack and/or get external exposure for predators or inclement weather. Once ready, the seeded-clay-balls rested in room conditions to get some drying and prevent sudden cracking under the overheated external temperature. The release period occurred 30 days before rainy season in the city of Palmas, state of Tocantins, Brazil, as recommended by Fukuoka (1991).

\section{Experiment Disposal onto the Soil}

The Nendo Dango method essentially says the it must be applied through no-tillage and randomly sowing the seeded-clay-balls onto the soil, which are subject for recovery/reforestation, but, in order to get research control and data acquisition, the experiment had to be designed with clear guidelines and field markings. For that, the chosen disposition was the zig-zag rule (Figure 3) and the field was isolated with zebra ribbon.

Each ball was interspaced only by $0.5 \mathrm{~m}$, whereas the experiment did not expect them grow into full form, i.e., just germination and pre-establishment period. At the end, the area was constituted by experiments of $8 \mathrm{~m}^{2}$, with 5 sample lines, 8 treatments (species) and 3 repetitions, totalizing $24 \mathrm{~m}^{2}$. The data acquisition occurred during 37 days, 3 times per week, using caliper rule, scaler and notepad. In the last day of counting/collecting data, the germination average rate was calculated.

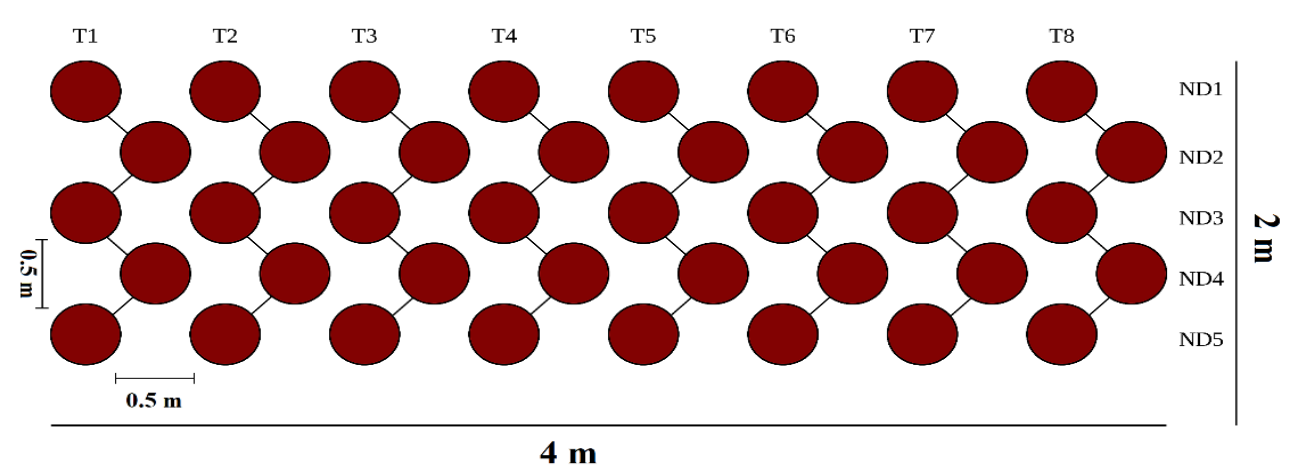

Figure 3: Design of the experimental field

\section{Statistical Analysis}

The treatments were outlined through completely randomized design with three repetitions/blocks, each repetition/block had eight treatments/species (Table 2) and each treatment had five samples, totalizing 40 clay balls for each repetition and 120 for the experiment.

For purposes of germination, the analyzed parameter was the number of germinated samples of each specie during the data acquisition period. Seeds which emerged seedlings elevating the cotyledons $5 \mathrm{~cm}$ above the soil were considered germinated (Brown, 1992). 
Table 2: Indication for treatment into statistical terms

\begin{tabular}{cc}
\hline TREATMENT $($ T) & SCIENTIFIC NAME \\
\hline T1 & Tabebuia roseoalba (Ridl.) Sandwith \\
T2 & Sterculia chicha A. St.-Hil. ex Turpin \\
T3 & Tabebuia heptaphylla (Vell.) Toledo \\
T4 & Anadenanthera falcata (Benth.) Speg \\
T5 & Calophyllum brasiliense Cambess \\
T6 & Guazuma ulmifolia Lam. \\
T7 & Hymenaea stigonocarpa Mart. ex Hayne \\
T8 & Bowdichia virgilioides Kunth \\
\hline
\end{tabular}

The data of germination percentage (GP) (Eq. 1), germination velocity rate (GVR) (Eq. 2) and required germination time (RGT) (Eq. 3) were analyzed under Tukey test with 5\% of probability, using the software Assistat 7.7 (Maguire, 1976; Labouriau \& Valadares, 1976; Silva \& Azevedo, 2006). The GVR is a rate calculated by means of counting the germinated seeds and has the goal of establish the differences in the germination velocity on accesses, groups and batches of seed, i.e., the greater the GVR value is, greater will be the daily germination, indication good treatment choice (Brasileiro et al., 2008).

$\mathbf{G P}=\frac{\mathrm{N}}{\mathrm{A}} \times 100$

Where GP means percentage of germination, $\mathrm{N}$ means total of germinated seeds and A means total of seeds sown to germinate.

$$
\mathbf{G V R}=\frac{\mathrm{G} 1}{\mathrm{~N} 1}+\frac{\mathrm{G} 2}{\mathrm{~N} 2}+\frac{\mathrm{G} 3}{\mathrm{~N} 3}+\cdots+\frac{\mathrm{Gn}}{\mathrm{Nn}}
$$

Where GVR means germination velocity rate, $G$ means number of seedlings in each counting, and $\mathrm{N}$ means number of days after clay balls release.

$$
\mathbf{R G T}=\frac{\sum \frac{N i}{T i}}{\sum N i}
$$

Where RGT means required germination time, Ni means number of seeds germinated in the nth day, and Ti means time (in days).

\section{RESULTS AND DISCUSSION \\ Germination Percentage (GP), Germination Velocity Rate (GVR) and Required Germination Time (RGT)}

Table 3 shows results obtained from the experiment after 37 days. The data indicated a slight variation among the species, whereas they presented, in general, a different behavior because of the conditions induced by the clay ball and/or the external environment. These differences may also be explained by the 
necessities that each specie has in order to germinate, as said before, because of scarification and/or dormancy break, which any of those were made/required by the technique.

Table 3: Amount (N), Germination Percentage (GP), Germination Velocity Rate (GVR) and Required Germination Time (RGT) for the species in the experiment

\begin{tabular}{|c|c|c|c|c|}
\hline SPECIE & $\mathbf{N}$ & GP & GVR & RGT \\
\hline Tabebuia roseoalba (Ridl.) Sandwith & $10 / 15$ & $66.67 \%$ & 0.90 & 0.22 \\
\hline Sterculia chicha A. St.-Hil. ex Turpin & $12 / 15$ & $80.00 \%$ & 1.08 & 0.26 \\
\hline Tabebuia heptaphylla (Vell.) Toledo & $8 / 15$ & $53.33 \%$ & 0.72 & 0.17 \\
\hline Anadenanthera falcata (Benth.) Speg & $15 / 15$ & $100.00 \%$ & 1.35 & 0.26 \\
\hline Calophyllum brasiliense Cambess. & $12 / 15$ & $80.00 \%$ & 1.08 & 0.26 \\
\hline Guazuma ulmifolia Lam. & $4 / 15$ & $26.67 \%$ & 0.36 & 0.18 \\
\hline Hymenaea stigonocarpa Mart. ex Hayne & $15 / 15$ & $100.00 \%$ & 1.35 & 0.26 \\
\hline Bowdichia virgilioides Kunth & $11 / 15$ & $73.33 \%$ & 0.99 & 0.24 \\
\hline TOTAL & $87 / 120$ & $72.5 \%$ & - & - \\
\hline
\end{tabular}

Among the germinated species, only Calophyllum brasiliense Cambess and Hymenaea stigonocarpa Mart. ex Hayne are classified as secondary, which can indicate that even needing shading to grow within the ecological succession, they distinctly presented satisfactory outcomes when put under the "Nendo Dango" technique. This may have occurred because of the microclimate generated within the clay ball, protecting the seeds on their early stages of development under the local high temperatures, turning to be a positive factor for their fixation in reforesting projects using this method.

The table data also shows that the species presented very similar RGT, i.e., even all the seeds did not have turn into seedlings, their timing to germinated was almost the same. It is noticeable when looking at Guazuma ulmifolia Lam and Tabebuia heptaphylla (Vell.) Toledo, which had the lowest GP, but, even so, presented a high RGT.

\section{Experiment Yields and Statistical Analysis}

As mentioned before, the experiment counted with 3 repetitions. In the first (R1) there was a total of 40 seeds which 33 had germinated, yielding $82.5 \%$. R2 had 40 seeds as well, germinating 30 and yielding $75 \%$. Repetition R3 also had 40 seeds and had germinated 24, yielding $60 \%$. The results from the Nendo Dango technique indicated differences when analyzing the yields of each repetition and of each specie. An example for that is the R3 yield of $60 \%$, when compared to the $100 \%$ germination of Hymenaea stigonocarpa Mart. ex Hayne, within this same repetition. Table 4 shows the statistical analysis of the data obtained from GP, GVR and RGT. The species Anadenanthera falcata (Benth.) Speg. and Calophyllum brasiliense Cambess did not presented significant differences on the GP and GVR, and the main hypothesis may be because the results' similarity and the way that the seeds were disposed next to each other, i.e., under the same external environment conditions. 
Table 4: Statistical analysis for GP, GVR and RGT at the end of 37 days*

\begin{tabular}{cccc}
\hline TREATMENT $($ T) & GP & GVR & RGT \\
\hline T1 & $66.67^{\mathrm{b}}$ & $0.90^{\mathrm{b}}$ & $0.22^{\mathrm{a}}$ \\
T2 & $80.00^{\mathrm{a}}$ & $1.08^{\mathrm{a}}$ & $0.26^{\mathrm{a}}$ \\
T3 & $53.33^{\mathrm{b}}$ & $0.72^{\mathrm{b}}$ & $0.17^{\mathrm{a}}$ \\
T4 & $100.00^{\mathrm{a}}$ & $1.35^{\mathrm{a}}$ & $0.26^{\mathrm{a}}$ \\
T5 & $80.00^{\mathrm{a}}$ & $1.08^{\mathrm{a}}$ & $0.26^{\mathrm{a}}$ \\
T6 & $26.67^{\mathrm{b}}$ & $0.36^{\mathrm{b}}$ & $0.18^{\mathrm{a}}$ \\
T7 & $100.00^{\mathrm{a}}$ & $1.35^{\mathrm{a}}$ & $0.26^{\mathrm{a}}$ \\
T8 & $73.33^{\mathrm{b}}$ & $0.99^{\mathrm{b}}$ & $0.24^{\mathrm{a}}$ \\
\hline
\end{tabular}

*Tukey test at $5 \%$ probability. Data followed by the same letter did not differ statically among each other.

The other species from the experiment had shown significant differences when analyzed under the parameters of GP and GVR. An explanation for it is the results' difference related to the GP, influenced by the same variables. Overall, the experiment did not show significant differences related to RGT when compared among the species, possibly explained by the similar beginning time for germination, early in the 37 days of experimentation.

According to Santos et al. (2004), in a study carried out for Sterculia chicha A. St.-Hil. ex Turpin germination analysis, when adopted scarification, the GP results were between $20 \%$ and $60 \%$, and, when not scarified, $50 \%$. Silva et al. (2015), in a similar study, obtained GP between $20 \%$ and $40 \%$. The same authors reported that the seed takes within 20 to 30 days to germinate. With the Nendo Dango technique it took 17 days.

Studies carried out by Oliveira et al. (2012) and Sena et al. (2017), using the Anadenanthera falcata (Benth.) Speg., registered GP varying from 68\% to $100 \%$, when treated with vermiculite, sand and humus, without any light, applying temperature around $25^{\circ}$ to $30^{\circ} \mathrm{C}$. NCPI - Northern Center of Plants Information (2003) found out the germination time to be within 2 to 33 days. Using Nendo Dango, this specie took 2 days to germinate.

Grabias et al. (2013) performed an experiment using Calophyllum brasiliense Cambess, sown with vermiculite, obtaining GP between $60.83 \%$ and $63.33 \%$. Nery et al. (2007) tested seeds of the same specie, scarifying it and putting under thermic conditions of 25 to $30^{\circ} \mathrm{C}$, also using as substratum a Germitest ${ }^{\circledR}$ paper roll wet with distillated water, which has resulted GP between $70 \%$ and $88 \%$. Carvalho (1994) says that this specie's germination normally occurs within 6 months, and, for the experiment developed, the Nendo Dango technique presented germination in 17 days.

Figliolia et al. (2009) tested Guazuma ulmifolia Lam putting the seed under treatment with vermiculite in laboratory and registered GP of 55 to $66 \%$. Barboza et al. (2014) says that the GP for this specie, when put under treatment with thermal shocks around $80^{\circ} \mathrm{C}$ and $100^{\circ} \mathrm{C}$, can vary from $73 \%$ to $76 \%$. Scalon et al. (2004) observed in seeds of Guazuma ulmifolia Lam GP from $71.7 \%$ to $73.3 \%$, when treating it with infusions on boiling water during 5 and 10 minutes. 
Nunes et al. (2006) verified that when exposing the seed to $70^{\circ} \mathrm{C}$ heat and staying still until reaches $50^{\circ} \mathrm{C}$ (taking approximately 30 minutes), it presented GP of 66.8\%. Barroso et al. (1993) and Ramos et al. (1998) indicate that this specie takes within 6 to 14 days to germinate, and, when using Nendo Dango, it took 19 days.

In early studies, Hymenaea stigonocarpa Mart. ex Hayne presented GP between $7 \%$ to $78.3 \%$ (Moraes et al., 2001), taking between 9 to 60 days to germinate after sown, under conditions of pre-germination treatment, with manual scarification, using emery paper on the opposite side of the germinal axis (Carvalho, 2007). Using Nendo Dango this specie took 13 days to germinate. Other studies using different types of scarification obtained GP results from $37 \%$ to $52 \%$ in vegetation houses and $52 \%$ to $86 \%$ in laboratory (Carvalho et al., 2005).

In the experiment of Duarte et al. (2010), the germination of Tabebuia roseoalba (Ridl.) Sandwith occurred between 8 to 18 days, considering that they were scarified, and presented GP of $40 \%$. Lorenzi (1992) argues differently saying that its dormancy only breaks within 3 months, and, in his study, his experiment's goal was to confront some germination data and verify if, in natural conditions, the GP would occur using the same Duarte et al. (2010) applied methodology. In this experiment, using Nendo Dango, the specie took 15 days to germinate.

Lorenzi (1992) also tested the germination of Tabebuia heptaphylla (Vell.) Toledo and said that, if scarified, the specie germinates within 10 to 12 days. In his experiment the GP was 60\%. Applying Nendo Dango enabled this specie to germinate in 20 days.

For Bowdichia virgilioides Kunth, according to Marcos Filho (2005), the main cause of its seed dormancy is the tegument impermeability and hardness. Studies made for this specie's germination presented GP from $2.1 \%$ to $11 \%$, when manually or chemically scarified (Schatral \& Fox, 1994; Allen \& Meyer, 1998). The same authors point out that it takes up 5 to 20 days to germinate, and, in this study, Nendo Dango made it happen within 16 days.

\section{CONCLUSIONS}

The Nendo Dango technique, in this study, considering all the taken conditions, well proved its efficiency on germination and pre-establishment of the seeds and seedlings into the deforested area used as experimental field. Comparing to the literature, most of the chosen species for this experiment had similar germination time and percentage. Not specific studies for GVR (germination velocity rate) and RGT (required germination time) were found to compare the results to, which opens up possibilities to expand the literature data about this subject. Speaking of further studies, it's fundamental that improvements must be done to enhance the technique in terms of inserting scarification, breaking of dormancy and/or pre-treatment of the seed before sown at the field, helping it to be even more successful. 


\section{ACKNOWLEDGMENTS}

The authors would like to thank the Laboratory of Environmental Impacts Characterization from the Federal University of Tocantins for the support, guidance and material supplied for the realization of this study.

\section{REFERENCES}

Allen, P. S., \& Meyer, S. E. (1998). Ecological aspects of seed dormancy loss. Seed Science Research, 8(2), 183-192.

Barboza, V. R. S., Pinto, M. A. D. S. C., Freire, C. S., \& Oliveira, C. K. S. (2014). Physiologic potential of Guazuma ulmifolia Lam. seeds. Biosphere Encyclopedia, 10(18), 2327-2335.

Barroso, D. G., Miranda, R. U., \& Marinho, C.S. (1993). Pre-germinating treatment of three native species from restinga wood at the region of Mataraca, Paraiba, Brazil. In: I Pan-American Forest Congress and VII Brazilian Forests Congress. Annals... Curitiba: SBEF, 476-477.

Bastos, L. A, \& Ferreira, I. M. (2010). Phytophysiognomics compositions of Cerrado biome: study about the Veredas' subsystem. Espaço em Revista, 12(1), 97-108.

Brasileiro, M. S., Carvalho, M. A., \& Karia, C.T. (2008). Correlation between seed weight and stamina and velocity of germination in Stylosanthes guianesis (Aubl.) Sw. In: IX National Cerrado Conference and II International Conference of Tropical Savannas. Annals... Brasilia, Federal District of Brazil.

Brown, D. (1992). Estimating the composition of a forest seed bank: a comparison of the seed extraction and seedling emergence methods. Can J Bot, 70(8), 1603-1612.

Carvalho, P. E. R. (1994). Brazilian forest species: forestry recommendations, potentialities and wood use. Brasilia: EMBRAPA.

Carvalho, P. E. R. (2007). Technical rotating: Hymenaea stigonocarpa. Embrapa Florestas, 133(1), 1-8.

Carvalho, P. S., Miranda, S. C., and Santos, M. L. (2005). Germination and biometric data of Hymenaea stigonocarpa Mart. E. Payne (leguminous caesalpinioideae): Jatobá-do-Cerrado. Revista Anhanguera, 6(1), 101-116.

Duarte, A. P. M., Filho, P. R. M. S., Abbade, L. C., \& Takaki, M. (2010). Anemocoria in "Ipê-branco" (Bignoniaceae). Naturalia, 33(1), 1-7.

Figliolia, M. B, Aguiar, I. B, \& Silva, A. (2009). Seed germination of three Brazilian tree species. Rev. Inst. Flor., 21(1), 107-115.

Fukuoka, M. (1985). The natural path of cultivation: theory and practice of a green philosophy. Valencia: Terapión.

Fukuoka, M. (1991). The natural way of farming. Translated by Frederic P. Metreaud. Tokyo and New York: Japan Publications.

Grabias, J., Rego, G. M., \& Guédes, E. C. (2013). Seed germination of Calophyllum brasiliense Cambess. from different provenances and collecting seasons. Revista Evinci, 253(1), 1-12.

Labouriau, L. G., \& Valadares, M. E. B. (1976). On the germination of seeds Calotropis procera (Ait.) Ait.f. Annals of the Brazilian Science Academy, 48(2), 263-284.

Lorenzi, H. (1992). Brazilian trees: identification manual and cultivar of Brazilian native trees. Nova Odessa: Plantarum.

Maguire, J. D. (1962). Speed of germination - aid and selection and evaluation for seedling emergence and vigor. Crop Science, 2(2), 176-177.

Marcos Filho, J. (2005). Seed's physiology of farmed plants. Piracicaba: FEALQ. 
Moraes et al. (2001) Chemical composition of Hymenaea stigonocarpa. Informativo ABRATES, 11(2), 264-279.

Nery, F. C., Alvarenga, A. A., Justo, C. F., Dousseau, S., \& Vieira, C. V. Effects of temperature and tegument on the germination of Calophyllum brasiliense seeds. Cienc. Agrotec., 31(6), 1872-1877.

Northern Center of Plants Information (NCPI). (2003). Angico (Anadenanthera colubrine (Vell.) Brenan): Basic information about the plant. Recife: Association of Northern Plants (ANP). Available at: http://www.cnip.org.br/PFNMs/angico.html.

Nunes, Y. R. F., Fagundes, M., Santos, M. R., Braga, R. F., \& Gonzaga, A. P. D. (2006). Germination of Guazuma ulmifolia Lam. (Malvaceae) e Heteropterys byrsonimifolia A. Juss (Malpighiaceae) under different tegument scarification treatments. Uniformes Científica, 8(1), 43-52.

Oliveira, K. S., Aloufa, K. S. O., \& Ibrahim, M. A. (2012). The influence of substratum on the seed's germination of Anadenanthera colubrine (Vell.) Brenan, under vegetation-house condition. Revista Arvore, 36(6), 1073-1078.

Ramos, R. P., Araujo, M. G., Brandão, M., Carvalho, P. G. S., Fonseca, M. B., \& Câmara, E. M. V. C. et al. (1991). Interrelations of soil, flora and fauna on the Pardo Grande riverbank at Minas Gerais, Brazil. Daphne, 1(3), 13-16.

Santos, T. O., Morais, T. G. O., \& Matos, V. P. (2004). Mechanic scarification on "Chichá" seeds. Revista Arvore, 28(1), 1-6.

Scalon, S. P. Q., Ramos, M. B. M., Scalon Filho, H., Mussury, R. M., \& Vierira, M. C. (2004). Pre-germinating treatment on Guazuma ulmifolia Lam. seeds germination. Horticultura Brasileira, 22(2), 343-350.

Schatral, A., \& Fox, J. E. D. (1994). Quality and viability of seeds in the genus Hibbertia. Seeds Science and Technology, 22(2), 273-284.

Sena, F. H., Lustosa, B. M., \& Almeida-Cortez, J. S. (2010). Ecophysiology of seed germination of Anadenanthera colubrine (Vell.) Brenan (Fabaceae). Gaia Scientia, 11(4), 1-8.

Silva, K. B., Pinto, M. S. C., Melo, E. N., Pereira, L. M., Dantas, L. T., Bezerra, M. D. et al. (2015). Effect of different substrates on emergence the growth seedlings of "Chichá-do-Cerrado" (Sterculia striata A. St. Hill. \& Naudin) Sterculiaceae. Revista Agropecuaria Técnica, 36(1), 176-182.

Silva, F. de A. S. E., \& Azevedo, C. A. V. de. A. (2006). New Version of the AssistatStatistical Assistance Software. In: World Congress on Computers in Agriculture, 4, Orlando-FL-USA: Annals... Orlando: American Society of Agricultural and Biological Engineers.

Torres, E. A. B. (2010). Final report on the implementation of ecological restoration models in disturbed areas of Bogotá. In: Government of Colombia, Colombia. Bogota: National Publisher, p. 59. 